\title{
Valoarea predictivă a biomarkerilor proinflamatori serici în pneumoniile copilului şi corelații clinico-terapeutice
}

\author{
Titiana Cornelia Cotoi' ${ }^{1}$ Raluca Niculescu² ${ }^{2}$ Adrian-Horațiu Sabău², Lorena Meliț ${ }^{3}$, \\ Oana Cristina Mărginean ${ }^{3}$, Adina Huțanu ${ }^{4,5}$, Daniela Lucia Muntean ${ }^{6}$ \\ ${ }^{1}$ IOSUD, Universitatea de Medicină, Farmacie, Științe și Tehnologie \\ "George Emil Palade", Tg. Mureș, România \\ ${ }^{2}$ Departamentul Patologie, Mureș County Clinical Hospital, Tg. Mureș, România \\ ${ }^{3}$ Clinica Pediatrie, Universitatea de Medicină, Farmacie, Știinţe și Tehnologie \\ "George Emil Palade", Tg. Mureș, România \\ ${ }^{4}$ Departamentul Medicină de Laborator, Universitatea de Medicină, Farmacie, Știinţe și Tehnologie \\ "George Emil Palade", Tg. Mureș, România \\ ${ }^{5}$ CCAMF, Universitatea de Medicină, Farmacie, Știinţe și Tehnologie \\ "George Emil Palade“, Tg. Mureș, România \\ ${ }^{6}$ Facultatea de Farmacie, Universitatea de Medicină, Farmacie, Știinţe și Tehnologie „George Emil Palade", \\ Tg. Mureș, România
}

\begin{abstract}
REZUMAT
Introducere. Pneumoniile la copii determină o rată mare a morbidității și mortalității, în special la copiii mici. Evoluția și prognosticul sunt influențate de o serie de parametri clinico-biologici, în raport cu vârsta copilului și cu terapia primită.

Obiective. Evaluarea statusului proinflamator la pacienții cu pneumonie.

Material și metode. Studiul a fost realizat în cadrul Clinicii Pediatrie I din cadrul Spitalului Clinic Județean de Urgență din Târgu Mureș, România, în perioada septembire 2018 - decembrie 2019, și a inclus 95 de pacienți.

Rezultate. Analiza nivelului seric al proteinei C reactive, varianta înalt-senzitivă (hsCRP), a arătat o corelație pozitivă, semnificativ statistică între nivelul la internare și numărul de neutrofile la internare $(p=03169, r=0,2801)$, respectiv o corelație negativă, semnificativ statistică între nivelul la externare și nivelul leucocitelor $(p=0,0253, r=-0,2911)$, monocitelor $(p=0,0014, r=-0,4105)$ și neutrofilelor $(p=0,0335, r=-0,2793)$ la externare. Dintre cele trei citokine monitorizate (IL-1 $\beta$. IL-6 și TNF- $\alpha$ ), au fost observate corelații semnificativ statistic pentru TNF- $\alpha$. Astfel, a fost identificată o corelație pozitivă, semnificativ statistică între valorile limfocitelor ( $p=0,0007, r=0,3448)$, monocitelor $(p=0,00563, r=0,2896)$ și ale trombocitelor $(p=0,0335, r=0,2195)$ la internare cu valorile markerului seric TNF-a. De asemenea, a fost identificată o corelație negativă, semnificativ statistică între valorile hemoglobinei $(p=0,0034$, $r=-0,328)$ și ale hematocritului ( $p=0,0004, r=-0,3932)$ la externare cu valorile markerului seric TNF- $\alpha$. Au fost observate următoarele corelații: corelație negativă, semnificativ statistică între TNF- $\alpha$ și NLR $(p=0,0144, r=-0,2601)$, NPR $(p=0,0473, r=-0,2051)$ și PLR $(p=0,0138, r=-0,2602)$, corelație pozitivă, semnificativ statistică între hsCRP la internare și NLR $(p=0,0124, r=0,3264)$, NPR $(p=0,0073, r=0,3460)$ și corelație pozitivă, semnificativ statistică între hsCRP la externare și NLR ( $p=0,0189, r=0,3128)$, PLR $(p=0,0036, r=0,3831)$.

Concluzii. Studiul nostru a arătat că valorile neutrofilelor, limfocitelor, monocitelor și trombocitelor, NLR, PLR și TNF- $\alpha$ au fost semnificativ crescute în pneumonii, corelându-se și cu PCR, subliniind statusul inflamator precoce apărut în acestă afecțiune.
\end{abstract}

Cuvinte cheie: pneumonii la copii, citokine, IL-1 $1 \beta$, IL-6, TNF- $\alpha$, antibioterapie

\section{INTRODUCERE}

Pneumoniile la copii au o rată mare a morbidităţii şi mortalităţii, în special la copiii mici (1). Evoluţia și prognosticul sunt influențate de o serie de parametri clinico-biologici, inclusiv cu prezența sau absența vaccinării, în raport cu vârsta copilului: nou-născut, sugar, copil mic, copil mare. Cazurile severe, cu răspuns terapeutic slab, sunt adesea urmate de decesul pacientului (2). 
Factorii de risc pentru infecțiile respiratorii severe sunt: prematuritatea sau greutatea mică sau foarte mică la naștere (low birthweight - LBW sau very low birthweight - VLBW), pacienții cu vârsta sub 3 luni, pacienţii $\mathrm{cu}$ malformaţii congenitale cardiace (pacienţii cu shunt stânga-dreapta), malformaţii congenitale pulmonare sau alte patologii cronice (insuficiență cardiacă, boli pulmonare obstructive cronice, diabet etc.) $(3,4)$. Alți factori importanți sunt reprezentaţi de lipsa alimentației naturale, malnutriția, rahitismul, anemia, diatezele exsudative, disfuncțiile imunologice, bolile anergizante, precum și condițiile socio-economice precare ale familiei copilului $(5,6)$.

Etiologia pneumoniilor la copii variază foarte mult în funcție de vârstă și se suprapune doar parțial cu ceea ce se întâmplă la populația adultă (7). Astfel, începând de la nou-născuți până la vârsta de 3 săptămâni, predomină infecțiile bacteriene cu Streptococcus grup B, unii germeni Gram negativi și Streptococcus pneumoniae. După vârsta de 3 săptămâni, până în primele trei luni de viață, predomină infecțiile virale cu virusul sincițial respirator, rinovirusuri, parainfluenza virus, influenza virus, adenovirus, la care se adaugă și infecțiile bacteriene cu Streptococcus pneumoniae, $H$. influenzae. După vârsta de 4 luni, până la 4 ani, pe lângă cele de mai sus, apar și Mycoplasma pneumoni$a e$, Streptococcus grup A. Peste vârsta de 5 ani, predomină infecțiile virale cu Mycoplasma pneumoniae, Streptococcus pneumoniae, Chlamydophila pneumoniae, $H$. influenzae, iar infecțiile virale sunt mai rare, fiind reprezentate de influenza virus, adenovirus, alte virusuri respiratorii (8-10).

Alături de analizele de laborator uzuale, tot mai multe studii raportează rolul biomarkerilor în identificarea statusului inflamator (citokinele inflamatorii interleukina-1 (IL-1), interleukina-6 (IL-6), interleukina-12 (IL-12) şi factorul de necroză tumorală $\alpha$ $(\mathrm{TNF}-\alpha)$ ) și a stresului oxidativ (catalaza, capacitatea totală antioxidantă, superoxiddesmutaza, raportul glutation oxidat/glutation redus) $(11,12)$.

\section{SCOP}

Scopul studiului constă în evaluarea statusului proinflamator la copiii cu pneumonie tratată cu antibiotice.

\section{MATERIAL ȘI METODE}

Studiul a fost unul prospectiv, realizat în cadrul Clinicii Pediatrie I din cadrul Spitalului Clinic Județean de Urgență din Târgu Mureș, România, în perioada septembrie 2018 - decembrie 2019, și a inclus 95 de pacienți, cu vârsta cuprinsă între o lună și
16 ani. Criteriile de includere în studiu au cuprins: copii cu pneumonie, internați în Clinica de Pediatrie, la care s-a obținut consimțământul informat din partea părinților sau a tutorilor legali. Criteriile de excludere au inclus: alte patologii infecțioase sau noninfecțioase ale altor sisteme de organe și lipsa de colaborare din partea aparținătorilor.

Variabilele analizate au fost: vârsta pacientului, sexul pacientului, greutatea pacientului, diagnosticul la internare, hemoleucograma la internare și la externare, valorile proteinei $C$ reactive, varianta înalt senzitivă (hsCRP) la internare și la externare, nivelurile serice ale IL-1 $\beta$, IL- 6 și TNF- $\alpha$, antibioterapia, evoluția pacientului și numărul de zile de spitalizare.

În scopul determinării nivelului seric al citokinelor, s-au folosit tehnica multiplex și tehnologia xMAP, pe analizorul Flexmap 3D, folosind trusa Human Cytokine Magnetic bead panel Milliplex, conform instrucțiunilor date de producător. Caracteristicile de performanță ale trusei: limita de detecție de $1,2 \mathrm{pg} / \mathrm{ml}$ pentru TNF- $\alpha, 1,0 \mathrm{pg} / \mathrm{ml}$ pentru IL- $1 \beta$ și $1,3 \mathrm{pg} / \mathrm{ml}$ pentru IL-6, și coeficientul de variație intra- și interrun sub $5 \%$, respectiv $15 \%$.

Statistica descriptivă și analitică a fost realizată folosind soft-urile SPSS v 17.0, GraphPad Prism 8 și XLSTAT-Lite 2015 pentru Windows 10 Pro. În vederea eliminării valorilor aberante, a fost efectuat testul Grubbs. Înaintea aplicării testelor de corelație, a fost aplicat testul Kolmogorov-Smirnov. În vederea realizării corelațiilor dintre valorile din hemoleucogramă și nivelurile serice ale IL-1 $\beta$, IL-6 și TNF- $\alpha$, a fost efectuat testul Pearson pentru datele parametrice și testul Spearman pentru datele nonparametrice. Pragul de semnificaţie ales pentru valoarea $\mathrm{p}$ a fost 0,05 .

Toţi părinţii sau aparţinătorii au semnat consimţământul informat pentru includerea copiilor în studiu. Studiul s-a desfăşurat conform principiilor Declarației de la Helsinki și a fost aprobat de Comisia de Etică a Universității de Medicină, Farmacie, Științe și Tehnologie „George Emil Palade“ din Tg. Mureș nr. $71 / 27.04 .2018$

\section{REZULTATE}

Vârsta medie a copiilor aflați în studiul nostru a fost de de 31,19+/-33,75 luni (cu limite cuprinse între o lună și 195 de luni (16 ani și 3 luni). În studiul nostru, majoritatea cazurilor de infecții respiratorii s-au înregistrat în primii doi ani de viață: 63 de cazuri $(66,31 \%)$, dintre care în primul an de viață 41 de cazuri $(43,15 \%)$ și 22 de cazuri $(23,15 \%)$ în al doilea an de viață. Dintre factorii de risc prezenți la pacienții din grupul țintă menționăm: malnutriţia (12 cazuri $12,63 \%$ ), anemia (42 de cazuri - 44,21\%), cazuri so- 


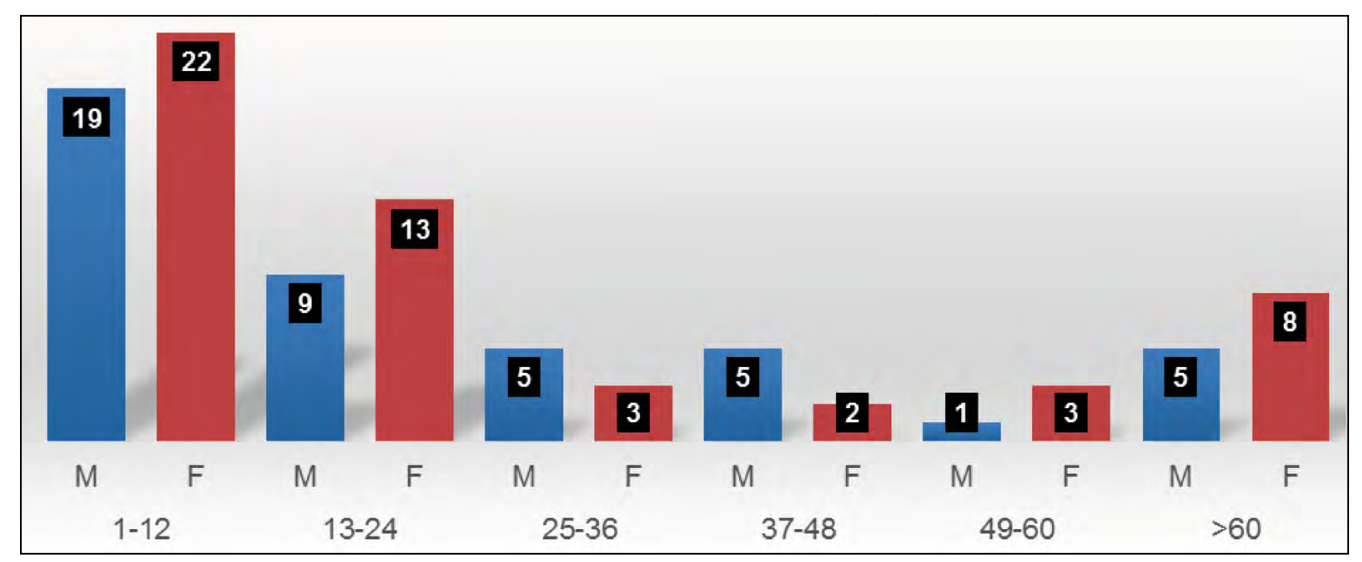

FIGURA 1. Distribuția pe grupe de vârstă și pe sexe a pacienților

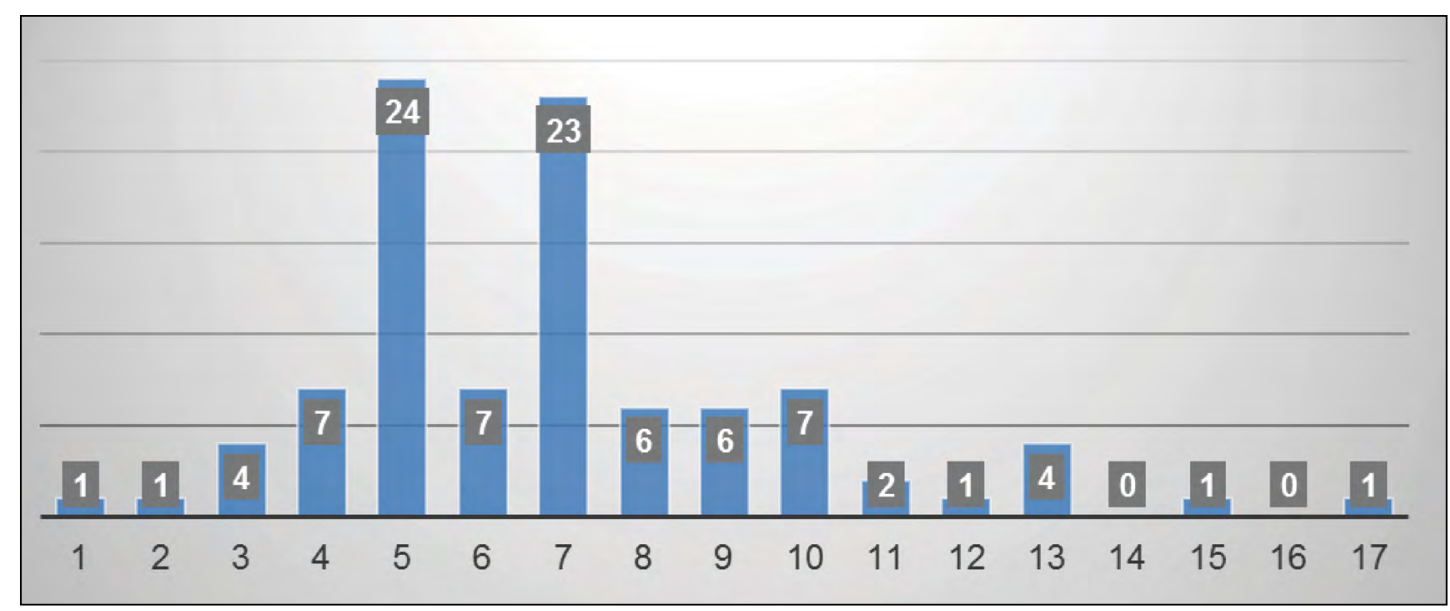

FIGURA 2. Distribuția cazurilor în funcție de numărul de zile de spitalizare

ciale ( 11 cazuri - 11,57\%), malformații cardiace congenitale cu shunt stânga-dreapta (DSA) (2 cazuri $2,10 \%)$ și epilepsie cu encefalopatie cronică ( $1 \mathrm{caz}$ $1,05 \%$ ). Distribuția pe sexe arată o ușoară predominență a sexului feminin, cu 51 de cazuri (53,68\%), față de pacienții de sex masculin, cu 44 de cazuri $(46,31 \%)$. Greutatea medie a pacienților a fost de $11,4+/-7,52 \mathrm{~kg}$, cu o minimă de $3.5 \mathrm{~kg}$ și o maximă de $47 \mathrm{~kg}$. Distribuția pe sexe și grupe de vârstă a cazurilor luate în studiu este ilustrată în figura 1 .

Un parametru important urmărit a fost numărul de zile de spitalizare, care a variat de internare de 1 zi până la 15 sau 17 zile la cazuri severe, cu o medie de 6,91 zile (standard deviation SD +/- 2,82) zile pentru tot grupul de studiu. Dintre cei 95 de pacienți incluși în studiu, 88 de pacienți au avut o evoluție favorabilă, iar pacienții cu multiple comorbidități au fost externați în stare ameliorată. Reprezentarea grafică în funcție de numărul de zile de internare este prezentată în figura 2.
Tratamentele propuse pentru pacienții cu pneumonie din grupul nostru au inclus administrarea de antibiotice la 68 de pacienți $(71,27 \%)$. Din totalul de 68 dintre pacienţi care au urmat tratament antibiotic, 63 au avut evoluție favorabilă. La 5 pacienți nu s-a produs ameliorarea simptomatologiei sub tratamentul iniţial și au necesitat adăugarea unui alt antibiotic sau înlocuirea tratamentului iniţial cu o nouă schemă de tratament. Cei mai mulți dintre pacienți au primit Ceftriaxonă în monoterapie (27 de pacienți - 39,70\% dintre cei tratați cu antibiotice). Ampicilina, în monoterapie, a fost administrată la 17 pacienţi (25\% dintre cei tratați cu antibiotice). Alte antibiotice administrate au fost: Clindamicina (16 pacienți - 23,52\%), Cefuroxim (6 pacienți - 8,82\%), Amoxicilina cu acid clavulanic (1 pacient - 1,47\%) și Claritromicina (1 pacient - 1,47\%). Toți pacienții trataţi cu Cefuroxim sau Ampicilină, fie în monoterapie, fie în combinație cu alt antibiotic, au avut o evoluţie favorabilă. 
TABELUL 1. Corelațiile dintre parametrii hematologici și markerii inflamatori

\begin{tabular}{|c|c|c|c|c|c|c|c|c|c|}
\hline \multirow{2}{*}{\multicolumn{2}{|c|}{$\begin{array}{l}\text { Variabile } \\
\text { analizate }\end{array}$}} & \multicolumn{2}{|c|}{ IL-1 $\boldsymbol{\beta}$ pg/ml } & \multicolumn{2}{|c|}{ IL-6 pg/ml } & \multicolumn{2}{|c|}{ TNF $\alpha \mathrm{pg} / \mathrm{ml}$} & \multicolumn{2}{|c|}{ PCR mg/dl } \\
\hline & & $n$ & $p$ & $n$ & $p$ & $n$ & $p$ & $n$ & $p$ \\
\hline \multirow[b]{2}{*}{$\begin{array}{l}\mathrm{Hb} \\
\mathrm{g} / \mathrm{dl}\end{array}$} & Internare & 67 & 0,5668 & 66 & 0,4178 & 94 & 0,1594 & 61 & 0,3527 \\
\hline & Externare & 59 & 0,1461 & 55 & 0,7432 & 78 & $\begin{array}{c}\mathbf{0 , 0 0 3 4} \\
r=-0,328\end{array}$ & 59 & 0,3240 \\
\hline \multirow[b]{2}{*}{$\mathrm{Htc} \%$} & Internare & 66 & 0,6429 & 66 & 0,4999 & 94 & 0,0724 & 61 & 0,2768 \\
\hline & Externare & 58 & 0,2371 & 55 & 0,5196 & 78 & $\begin{array}{c}\mathbf{0 , 0 0 0 4} \\
r=-0,393\end{array}$ & 59 & 0,1292 \\
\hline \multirow{2}{*}{$\begin{array}{l}\text { Le } \\
10^{3} / \mu \mathrm{l}\end{array}$} & Internare & 65 & 0,8799 & 64 & 0,3419 & 92 & 0,1914 & 61 & 0,8109 \\
\hline & Externare & 58 & 0,5174 & 55 & 0,4596 & 78 & 0,6411 & 59 & $\begin{array}{c}\mathbf{0 , 0 2 5 3} \\
r=-0,2911\end{array}$ \\
\hline \multirow{2}{*}{$\begin{array}{c}\mathrm{Li} \\
10^{3} / \mu \mathrm{l}\end{array}$} & Internare & 66 & 0,9194 & 66 & 0,7565 & 93 & $\begin{array}{c}\mathbf{0 , 0 0 0 7} \\
r=0,3448\end{array}$ & 60 & 0,0605 \\
\hline & Externare & 56 & 0,3478 & 53 & 0,4631 & 76 & 0,0626 & 58 & 0,3896 \\
\hline \multirow{2}{*}{$\begin{array}{c}\text { Mo } \\
10^{3} / \mu l\end{array}$} & Internare & 64 & 0,8380 & 63 & 0,1069 & 90 & $\begin{array}{c}\mathbf{0 , 0 0 5 6} \\
r=0,2896\end{array}$ & 60 & 0,9506 \\
\hline & Externare & 57 & 0,2267 & 54 & 0,3788 & 77 & 0,0990 & 58 & $\begin{array}{c}\mathbf{0 , 0 0 1 4} \\
r=-0,4105\end{array}$ \\
\hline \multirow{2}{*}{$\begin{array}{c}\mathrm{Ne} \\
10^{3} / \mu \mathrm{l}\end{array}$} & Internare & 66 & 0,5759 & 63 & 0,4649 & 90 & 0,2198 & 61 & $\begin{array}{c}\mathbf{0 , 0 3 1 7} \\
r=0,2801\end{array}$ \\
\hline & Externare & 56 & 0,8610 & 53 & 0,3050 & 76 & 0,1883 & 57 & $\begin{array}{c}\mathbf{0 , 0 3 5 4} \\
r=-0,2793\end{array}$ \\
\hline \multirow{2}{*}{$\begin{array}{c}\mathrm{T} \\
10^{3} / \mu \mathrm{l}\end{array}$} & Internare & 67 & 0,8598 & 66 & 0,9630 & 94 & $\begin{array}{c}\mathbf{0 , 0 3 3 5} \\
r=0,2195\end{array}$ & 59 & 0,0636 \\
\hline & Externare & 57 & 0,1529 & 54 & 0,3232 & 76 & 0,0723 & 59 & 0,8944 \\
\hline
\end{tabular}

Analiza statistică dintre nivelul seric al proteinei C reactive, varianta înalt-senzitivă (hsCRP), a arătat o corelație pozitivă, semnificativ statistică între nivelul la internare și numărul de neutrofile la internare $(\mathrm{p}=$ $0,3169, r=0,2801)$, respectiv o corelație negativă, semnificativ statistică între nivelul la externare și nivelul leucocitelor $(\mathrm{p}=0,0253, \mathrm{r}=-0,2911)$, monocitelor $(\mathrm{p}=0,0014, \mathrm{r}=-0,4105)$ şi neutrofilelor $(\mathrm{p}=0,0354, \mathrm{r}=-0,2793)$ la externare. Dintre cele trei citokine monitorizate, am obținute corelații semnificativ statistic pentru TNF- $\alpha$. Astfel, a fost identificată o corelație pozitivă, semnificativ statistică între valorile limfocitelor $(\mathrm{p}=0,0007, \mathrm{r}=0,3448)$, monocitelor $(\mathrm{p}=0,0056, \mathrm{r}=0,2896)$ și ale trombocitelor $(\mathrm{p}=$ $0,0335, r=0,2195$ ) la internare cu valorile markerului seric TNF- $\alpha$. De asemenea, a fost identificată o corelație negativă, semnificativ statistică între valorile hemoglobinei ( $\mathrm{p}=0,0034, \mathrm{r}=-0,328)$ și ale hematocritului $(\mathrm{p}=0,0004, \mathrm{r}=-0,393)$ la externare cu valorile markerului seric TNF- $\alpha$.

Analiza statistică a cuprins și raportul dintre neutrofile şi limfocite (NLR) $(\mathrm{n}=94)$ având o valoare medie de 3,003+/- 4,87, raportul dintre neutrofile și trombocite $(\mathrm{NPR})(\mathrm{n}=94)$ prezentând o valoare medie de 0,02 (SD +/- 0.02) și raportul dintre trombocite şi limfocite (PLR) $(\mathrm{n}=94)$ exprimând o valoare medie de $127,82+/-101,51$. Rezultatele obținute arată următoarele corelații: corelație negativă, semnificativ statistică între TNF- $\alpha$ și NLR ( $p=0,0144, r=-0,2601)$, NPR $(p=0,0473, r=-0,2051)$, PLR $(p=0,013, r=$ $-0,2602)$, corelație pozitivă, semnificativ statistică între hsCRP la internare și NLR $(\mathrm{p}=0,0124, \mathrm{r}=0,3264)$, NPR ( $p=0,0073, r=0,3460)$ și corelaţie pozitivă, semnificativ statistică între hsCRP la externare și NLR ( $p=0,0189, r=0,3128)$, PLR $(p=0,0036$, $\mathrm{r}=0,3031)$. Tabelul 2 prezintă valorile corelaţiilor realizate între aceste rapoarte și markerii inflamatori serici.

\section{DISCUŢII}

În cele mai multe cazuri, diagnosticul de pneumonie se stabiliește pe criterii clinice și radiologice. Există însă situații în care este nevoie de investigații suplimentare, mai ales în suprapunerea infecțiilor virale şi bacteriene (13).

Etiologia infecțiilor de tract respirator inferior diferă ușor la populația pediatrică față de populația adultă. La copii, infecțiile virale cuprind mai ales rinovirus, metapneumovirus (HMP) și virusul sinciţial respirator (RSV), iar dintre bacterii Haemophilus influenzae, Staphylococcus aureus și Streptococcus pneumoniae. De asemenea, tratamentul diferă între cele două populații, întrucât la copii se obține un răspuns foarte bun la betalactamine de tipul Amoxicilină/Ampicilină sau cefalosporine, pe când la adult, din 
TABELUL 2. Corelații statistice rapoarte leucocite și trombocite - markerii inflamatori serici

\begin{tabular}{|c|c|c|c|c|c|c|}
\hline \multirow{2}{*}{$\begin{array}{c}\text { Variabilele } \\
\text { analizate }\end{array}$} & \multicolumn{2}{|c|}{ NLR } & \multicolumn{2}{|c|}{ NPR } & \multicolumn{2}{|c|}{ PLR } \\
\hline & $n$ & $p$ & $n$ & $p$ & $n$ & $p$ \\
\hline IL-1 pg/ml & 63 & 0,3121 & 68 & 0,6993 & 63 & 0,4517 \\
\hline $\mathrm{IL}-6 \mathrm{pg} / \mathrm{ml}$ & 61 & 0,2093 & 66 & 0,5482 & 62 & 0,8522 \\
\hline TNF pg/ml & 88 & $\begin{array}{c}\mathbf{0 , 0 1 4 4} \\
r=-0,2601\end{array}$ & 94 & $\begin{array}{c}\mathbf{0 , 0 4 7 3} \\
r=-0,2051\end{array}$ & 89 & $\begin{array}{c}\mathbf{0 , 0 1 3 8} \\
r=-0,2602\end{array}$ \\
\hline PCR mg/dl - internare & 58 & $\begin{array}{c}\mathbf{0 , 0 1 2 4} \\
r=0,3264\end{array}$ & 59 & $\begin{array}{c}\mathbf{0 , 0 0 7 3} \\
r=0,3460\end{array}$ & 60 & 0,1230 \\
\hline PCR mg/dl - externare & 56 & $\begin{array}{c}\mathbf{0 , 0 1 8 9} \\
r=0,3128\end{array}$ & 59 & 0,2166 & 56 & $\begin{array}{c}\mathbf{0 , 0 0 3 6} \\
r=0,3831\end{array}$ \\
\hline
\end{tabular}

cauza rezistenței la antibiotice, adesea este nevoie de terapii combinate $(14,15)$.

În studiul nostru, 68 de pacienți dintre cei 95 $(71,27 \%)$ au avut pneumonii bacteriene și au necesitat tratament cu antibiotice. O metaanaliză publicată recent a monitorizat numeroase studii și review-uri din literatură privind tratamentele empirice cu antibiotice în cazul pneumoniilor la nou-născuți și copii. În acest articol, s-a demonstrat că, în ciuda numeroaselor ghiduri OMS sau a altor ghiduri internaționale, terapia cu antibiotice este încă foarte heterogenă. Pornind de la recomandările din ghidurile OMS, pneumonia la copii poate fi foarte severă, severă sau nonseveră. Antibioterapia se recomandă în formele foarte severe sau severe. Primele antibiotice recomandate sunt amoxicilina sau ampicilina, urmate de cefalosporinele de generaţia a treia (16).

Un studiu efectuat pe baza unor chestionare adresate către 120 de respondenți, majoritatea medici specialiști în pediatrie, a arătat că există diferențe foarte mari în ceea ce privește aderența medicilor prescriptori la recomandările ghidurilor internaţionale (17).

Conform recomandărilor American Academy of Pediatrics, la fiecare caz grav se va reevalua diagnosticul inițial. În caz de forme atipice de pneumonie, se vor căuta agenți etiologici atipici sau mai puțin comuni. În general, o pneumonie necomplicată se va vindeca în maximum 7 zile, sub tratament adecvat, inclusiv cu antibiotice. La pacienții care prezintă alte comorbidităţi, în special boli neuro-musculare, pneumoniile tind să fie severe și adesea cauzate de agenți infecțioși rezistenți la tratament (18). În studiul nostru, perioada medie de spitalizare a fost de 6,71 zile. Perioade mai lungi de spitalizare au fost înregistrate la pacienții cu comorbidități.

În studiul nostru, cele mai folosite antibiotice au fost Ceftriaxona, urmată de Ampicilină și Clindamicină. Claritromicina a fost folosită doar în cazul unui singur pacient. Studii recente arată că în prima linie pentru tratamentul pneumoniilor se află $\beta$-lactaminele.
Se preferă ca primul antibiotic pentru pacienții internaţi în spital să fie Penicilina G sau Ampicilina. La pacienții cu forme uşoare, se recomandă Amoxicilina, asociată sau nu cu acid clavulanic. Acest tratament poate fi administrat per oral la pacienții din ambulator. Macrolidele se recomandă mai ales în caz de pneumonii cu Mycoplasa pneumoniae sau Chlamydophila pneumoniae (19-21).

Un subiect des dezbătut în literatură este legat de factorii de risc externi. În această categorie se încadrează poluarea domestică sau indoor (condițiile socio-economice ale familiei, statusul nutrițional, igiena personală a membrilor familiei sau fumatul de către unul sau mai mulți membri ai familiei). Unul dintre cei mai importanţi factori de risc este lipsa vaccinării (imunizării), indiferent dacă este vorba este bacterii sau virusuri (inclusiv rujeola) (22). Prin aplicarea cu succes a vaccinării bivalente anti-Haemophilus influenzae tip B și Streptococcus pneumoniae, s-a redus foarte mult incidența infecțiilor respiratorii la copii, în special sub 5 ani. Practic, imunizarea s-a dovedit a fi cea mai importantă metodă de prevenție a pneumoniilor. Tratamentul recomandat pentru formele uşoare este reprezentat de antibioterapia per oral, iar în formele severe - antibioterapia parenteral (23). În studiul nostru au fost incluși și 11 pacienți consideraţi cazuri sociale.

Diagnosticul și managementul pacienților pediatrici cu pneumonie apelează la toate tipurile de investigații clinice și paraclinice: diagnostic imagistic, diagnostic microbiologic, teste de laborator - hemoleucogramă și markeri serologici (procalcitonina - PCT și proteina C reactivă). Fiecare dintre acestea ajută la diagnosticul diferențial dintre o pneumonie virală și una bacteriană, iar în final la indicația sau nonindicația terapiei cu antibiotice (24). Concentrația procalcitoninei (PCT) de sub 2,5 ng/ml se corelează cu infecțiile uşoare, iar concentrațiile mari se corelează cu formele severe, care necesită prezentarea la urgență și care se asociază cu apariția complicațiilor și prelungirea spitalizării. PCT ar putea fi folosită și ca 
biomarker pentru ghidarea necesității tratamentului cu antibiotice (25).

Într-un studiu multicentric retrospectiv de tip cohortă, s-a analizat prevalența bacteriemiei la copii cu vârste cuprinse între 3 luni și 18 ani care au fost internați pentru pneumonie. S-au analizat mai mulți parametri pentru a se identifica predictori pentru bacteriemie. Astfel, au fost efectuate curbele ROC pentru proteina $\mathrm{C}$ reactivă, VSH și leucocite. Cei mai importanți predictori ca factori independenți asociați cu bacteriemia au fost leucocitoza, aspectul radiologic caracteristic și complicațiile pleurale, prezentarea pacientului în urgență și numărul de zile de spitalizare.

În opinia autorilor, întrucât prevalența bacteriemiei a fost foarte mică, de 2,2\% (1 din 400 de pacienți), hemoculturile la acești pacienți ar trebui descurajate (26).

În studiul nostru, am monitorizat parametrii clasici pentru evaluarea statusului inflamator: hemoleucograma completă, temperatura corporală și proteina $\mathrm{C}$ reactivă la internare și la externare. Pentru stabilirea corelațiilor clinico-biologice, am dozat și markerii inflamatori moderni, din sângele recoltat la internare: IL-1 $\beta$, IL-6, TNF- $\alpha$.

Numeroase studii recente au raportat analiza biomarkerilor în diverse patologii infecțioase (pneumonii) sau noninfectioase (infarct miocardic acut sau boli cronice inflamatorii intestinale). Un studiu prospectiv observațional efectuat pe un grup de 66 de pacienți a analizat valoarea predictivă a pro-adrenomedulinei (Pro-ADM) și a interleukinei 1 beta (IL$1 \beta)$ pentru stratificarea severității bolii. Acești biomarkeri au fost determinați din probele de sânge recoltate de la pacienți în momentul internării și s-au analizat comparativ cu hemoleucograma și proteina $\mathrm{C}$ reactivă, în paralel cu severitatea bolii. Pro-ADM s-a dovedit cel mai bun biomarker pentru stratificarea severității bolii, iar ambii biomarkeri au avut valori serice mărite la pacienții cu complicații datorate bolii (27).

Alt studiu prospectiv de tip cohortă, care a inclus 196 de pacienţi cu pnemonie, a testat 21 de citokine și chemokine sistemice. Cele mai puternice asocieri din punct de vedere statistic s-au înregistrat între severitatea bolii și IL-6, IL-8, IL-13 și IFN- $\gamma$. La fel ca și în studiul nostru, nu s-au obținut corelații semnificativ statistic între numărul total de leucocite și citokine (28). De asemenea, s-a studiat raportul dintre IL-6 (citokină proinflamatorie) și IL-10 (citokină antiinflamatorie) pentru stabilirea severității bolii și a evoluției pacientului, respectiv încercarea de a stabili etiologia bacteriană sau virală a unei pneumonii (29).

Un studiu prospectiv care a cuprins 322 de pacienți cu vârsta de sub 5 ani, dintre care s-au selectat în final 166 de pacienți, a analizat numeroase citokine (IL-1 $\beta$, IL-2, IL-4, IL-5, IL-6, IL-8, IL-10, IL-12, TNF- $\alpha$ și IFN- $\gamma$ ) și chemokine (CCL2, CCL5, CXCL9, CXCL10). Dintre acestea, au avut valori detectabile IL-6, IL-8, IL-10, CCL2 și CXCL10. IL-6 a avut o valoare predictivă pentru pneumonia pneumococică (30). Un alt studiu a cuprins 430 de copii cu pneumonie severă și nonseveră la care s-au testat 27 de citokine. Dintre acestea, IL-6 și G-CSF (granulocytecolony stimulating factor) s-au corelat cu severitatea bolii (31).

Raportul dintre valorile elementelor figurate din sângele periferic și valoarea lor predictivă este un subiect foarte studiat în prezent. Acești indicatori se folosesc în boli inflamatorii cronice de tipul lupusului sistemic sau în sindromul metabolic $(32,33)$. Aceste rapoarte sunt deosebit de utile pentru evaluarea răspunsului la chimioterapie în diferite tipuri de cancere (34). De asemenea, au fost studiate în cazul pneumoniilor, atât la copii, cât și la adulți $(35,36)$. În studiul nostru, am analizat toate cele trei rapoarte, NLR, NPR și PLR, și am găsit corelații semnificativ statistice la pacienții pediatrici cu pneumonie, pentru hsCRP și TNF- $\alpha$.

Limitările principale ale studiului nostru sunt reprezentate de numărul relativ mic de pacienți incluși în studiu ( $(n=95)$, ca urmare a particularităţii patologiei, și efectuarea studiului doar într-un singur centru. Altă limitare a fost măsurarea biomarkerilor numai din sângele recoltat la internarea pacienților și analiza doar a unui număr mic de citokine (IL-1 $\beta$, IL-6 și TNF- $\alpha$ ), cu lipsa analizei altora deja raportate în literatură (procalcitonina, IL-8, IL-10, IFN- $\gamma$, CCL2 și CXCL10).

\section{CONCLUZII}

Pneumonia la copii se asociază cu un status inflamator de diferite grade în funcție de tipul pneumoniei. Studiul nostru a arătat că valorile neutrofilelor, limfocitelor, monocitelor și trombocitelor, NLR, PLR și TNF- $\alpha$ au fost semnificativ crescute în pneumonii, corelându-se și cu PCR, subliniind statusul inflamator precoce apărut în acestă afecțiune. Determinarea precoce a statusului inflamator asociat pneumoniei la copil este esenţială pentru a pune un diagnostic cât mai rapid și a preveni complicațiile ce pot apărea. 


\section{BIBLIOGRAFIE}

1. Arbo A, Lovera D, Martínez-Cuellar C. Mortality Predictive Scores for Community-Acquired Pneumonia in Children. Curr Infect Dis Rep. 2019;21(3):10.

2. DeAntonio R, Yarzabal JP, Cruz JP, Schmidt JE, Kleijnen J. Epidemiology of community-acquired pneumonia and implications for vaccination of children living in developing and newly industrialized countries: A systematic literature review. Hum Vaccin Immunother. 2016;12(9):2422-2440.

3. Fritz $C Q$, Edwards KM, Self WH, et al. Prevalence, Risk Factors, and Outcomes of Bacteremic Pneumonia in Children. Pediatrics. 2019;144(1):e20183090.

4. Nathan AM, Teh CSJ, Jabar KA, et al. Bacterial pneumonia and its associated factors in children from a developing country: A prospective cohort study. PLoS One. 2020;15(2):e0228056.

5. Dean P, Florin TA. Factors Associated With Pneumonia Severity in Children: A Systematic Review. J Pediatric Infect Dis Soc. 2018;7(4):323-334.

6. Krawiec M, Kraj G, Peradzynska J, Krauze A, Kulus M. Risk factors for local complications in children with community-acquired pneumonia. Clin Respir J. 2018;12(1):253-261.

7. Jain S, Self WH, Wunderink RG, et al. Community-Acquired Pneumonia Requiring Hospitalization among U.S. Adults. N Engl J Med. 2015;373(5):415-427.

8. Jain S, Williams DJ, Arnold SR, et al. Community-acquired pneumonia requiring hospitalization among U.S. children. $N$ Engl J Med. 2015;372(9):835-845.

9. Shi T, McLean K, Campbell H, Nair H. Aetiological role of common respiratory viruses in acute lower respiratory infections in children under five years: A systematic review and meta-analysis. J Glob Health. 2015;5(1):010408.

10. Slack MPE. The evidence for non-typeable Haemophilus influenzae as a causative agent of childhood pneumonia. Pneumonia (Nathan). 2017;9:9.

11. Principi N, Esposito S. Biomarkers in Pediatric Community-Acquired Pneumonia. Int J Mol Sci. 2017;18(2):447.

12. Nascimento-Carvalho EC, Vasconcellos ÂG, Clarêncio J, et al. Evolution of cytokines/chemokines in cases with community-acquired pneumonia and distinct etiologies. Pediatr Pulmonol. 2020;55(1):169176.

13. Yun KW, Wallihan R, Juergensen A, Mejias A, Ramilo O. CommunityAcquired Pneumonia in Children: Myths and Facts. Am J Perinatol. 2019;36(S 02):S54-S57.

14. Leung AKC, Wong AHC, Hon KL. Community-Acquired Pneumonia in Children. Recent Pat Inflamm Allergy Drug Discov. 2018;12(2):136144.

15. Rider AC, Frazee BW. Community-Acquired Pneumonia. Emerg Med Clin North Am. 2018;36(4):665-683.

16. Mathur S, Fuchs A, Bielicki J, Van Den Anker J, Sharland M. Antibiotic use for community-acquired pneumonia in neonates and children: WHO evidence review. Paediatr Int Child Health. 2018;38(sup1):S66S75.

17. McLaren SH, Mistry RD, Neuman MI, Florin TA, Dayan PS. Guideline Adherence in Diagnostic Testing and Treatment of Community-Acquired Pneumonia in Children [published online ahead of print, $2019 \mathrm{Feb}$ 14]. Pediatr Emerg Care. 2019;10.

18. Messinger Al, Kupfer O, Hurst A, Parker S. Management of Pediatric Community-acquired Bacterial Pneumonia. Pediatr Rev. 2017;38(9):394-409.
19. Nascimento-Carvalho AC, Nascimento-Carvalho CM. Clinical management of community-acquired pneumonia in young children. Expert Opin Pharmacother. 2019;20(4):435-442.

20. Blyth CC, Gerber JS. Macrolides in Children With Community-Acquired Pneumonia: Panacea or Placebo?. J Pediatric Infect Dis Soc. 2018;7(1):71-77.

21. Donà $D$, Luise $D, D a$ Dalt L, Giaquinto $C$. Treatment of CommunityAcquired Pneumonia: Are All Countries Treating Children in the Same Way? A Literature Review. Int J Pediatr. 2017;2017:4239268.

22. Gothankar J, Doke P, Dhumale G, et al. Reported incidence and risk factors of childhood pneumonia in India: a community-based cross-sectional study. BMC Public Health. 2018;18(1):1111.

23. le Roux DM, Zar HJ. Community-acquired pneumonia in children - a changing spectrum of disease. Pediatr Radiol. 2017;47(11):13921398.

24. Zar HJ, Andronikou S, Nicol MP. Advances in the diagnosis of pneumonia in children. BMJ. 2017;358:j2739.

25. Stockmann C, Ampofo K, Killpack J, et al. Procalcitonin Accurately Identifies Hospitalized Children With Low Risk of Bacterial Community-Acquired Pneumonia. J Pediatric Infect Dis Soc. 2018;7(1):46-53.

26. Lipsett SC, Hall M, Ambroggio L, et al. Predictors of Bacteremia in Children Hospitalized With Community-Acquired Pneumonia. Hosp Pediatr. 2019;9(10):770-778.

27. Korkmaz MF, Güzel A, Açıkgöz M, Okuyucu A, Alaçam H. Reliability of Pro-adrenomedullin and Interleukin $1 \beta$ in Predicting Severity of Community-Acquired Pneumonia in Pediatric Patients. Ann Clin Lab Sci. 2018;48(1):81-89.

28. Saghafian-Hedengren S, Mathew JL, Hagel E, et al. Assessment of Cytokine and Chemokine Signatures as Potential Biomarkers of Childhood Community-acquired Pneumonia Severity: A Nested Cohort Study in India. Pediatr Infect Dis J. 2017;36(1):102-108.

29. Conway SR, Doughty LA. Cytokine Help for Diagnosing CommunityAcquired Pneumonia. Pediatr Crit Care Med. 2017;18(4):391-393.

30. Vasconcellos ÂG, Clarêncio J, Andrade D, Cardoso MA, Barral A, Nascimento-Carvalho CM. Systemic cytokines and chemokines on admission of children hospitalized with community-acquired pneumonia. Cytokine. 2018;107:1-8.

31. Haugen J, Chandyo RK, Brokstad KA, et al. Cytokine Concentrations in Plasma from Children with Severe and Non-Severe Community Acquired Pneumonia. PLoS One. 2015;10(9):e0138978.

32. Qin B, Ma N, Tang Q, et al. Neutrophil to lymphocyte ratio (NLR) and platelet to lymphocyte ratio (PLR) were useful markers in assessment of inflammatory response and disease activity in SLE patients. Mod Rheumatol. 2016;26(3):372-376.

33. Liu CC, Ko HJ, Liu WS, et al. Neutrophil-to-lymphocyte ratio as a predictive marker of metabolic syndrome. Medicine (Baltimore). 2019;98(43):e17537.

34. Graziano V, Grassadonia A, lezzi L, et al. Combination of peripheral neutrophil-to-lymphocyte ratio and platelet-to-lymphocyte ratio is predictive of pathological complete response after neoadjuvant chemotherapy in breast cancer patients. Breast. 2019;44:33-38.

35. Huang Y, Liu A, Liang L, et al. Diagnostic value of blood parameters for community-acquired pneumonia. Int Immunopharmacol. 2018;64:10-15.

36. Cataudella E, Giraffa CM, Di Marca S, et al. Neutrophil-To-Lymphocyte Ratio: An Emerging Marker Predicting Prognosis in Elderly Adults with Community-Acquired Pneumonia. J Am Geriatr Soc. 2017; 65(8):1796-1801. 